\title{
Study of Treatment of Pregnancy and Childbirth in Waris Dictrict, Keerom Regency, Province of Papua Indonesia
}

\author{
Susana Ramandey ${ }^{1}$, Suryati Romauli ${ }^{2}$, Flora Niu ${ }^{3}$ \\ ${ }^{1,2,3}$ Health Polytechnic of Jayapura, School of Midwifery, Jalan Padang Bulan 2, Hedam, Kota Jayapura
}

\begin{abstract}
This research aims to examine in depth of treatment pregnancy and childbirth-tribes Walsa Keerom Regency waris District in the province of Papua. This study uses qualitative methods with an ethnographic approach. Informants in this study is pregnant and the mother of childbirth (mother descended from Walsa), families of pregnant women and mothers parturition (husband or parents of pregnant women and mothers parturition), midwives, herbalists and other indigenous tribes of Walsa. Data collection is done through the methods of the Focus Group Discussion, in-depth interviews, observation and documentation and passive participation. The results showed that the implementation of the care of expectant mothers tribe Walsa done by maintaining physical health, family support was given from the beginning of pregnancy of the mother, intertwined relationship between pregnant women with families, relatives and neighbors. Types of pregnancy examination is done traditionally by utilizing the services of a shaman at age 2-9 months of pregnancy. The women of the tribe Walsa also utilizes the services of midwives to checked her pregnancy gestational age when stepping on the moon. Diet pregnant women the same as his family's diet with main menu papeda (original food of Papuanes) and vegetable consumed in limited. There are culture specific food abstinence during pregnancy. Help and handling labor performed by the mother alone or shaman and assisted by relatives or neighbors. Place of delivery is done in the kitchen, the back room or hut specially made the husband behind the House. While Labor's husband is not allowed to accompany his wife to 3-4 weeks after the baby is born. The position used when maternity was the position of the squat. The cutting of the umbilical cord after the placenta (her brother) was born using a razor blade and placenta treatment done by burying it in the ground and adjusted the position of the House in the country
\end{abstract}

Keywords: Pregnancy, Care of Delivery, Tribes, Childbirth.

\section{Introduction}

Every pregnancy and its development has experienced a risk of difficulty or complications that will have an impact on maternal mortality. Pregnancy and childbirth care is done to help reduce the risk of death of mothers and babies, which in turn can reduce maternal mortality and infant mortality rate.

Demographic Health Survey results Indonesia 2012, the case of the death of mother jumped up, note mother mortality rate of 359 per 100,000 live births or increase of approximately $57 \%$ when compared to 2007 's condition, which only amounted to 228 per 100,000 live births. The figure also still high compared to Southeast Asian countries such as Singapore 3 per 100,000 live births, Malaysia 5 per 100,000 live births, Thailand 8-10 per 100,000 live births and in Viet Nam 50 per 100,000 live births (Kemenkes, 2013).

The who, The Millennium Development Goals, 2000. The main purpose of the eight commitments formulated in the field of health and one of them is lowering AKI and AKB through improved care of pregnancy or antenatal care is called. One of the indicators that are used to describe the access of pregnant women antenatal service coverage is against K1-the first contact on the first trimester of pregnancy and K4-contact four times on a trimester of pregnancy labor by health workers who have the competency standards.

The national basic health Research results 2013, States that the number of pregnancy examination with health workers already better i.e. $\mathrm{K} 1$ of $81.3 \%$ and $\mathrm{K} 4$ of $70.0 \%$, but there is still a $3.2 \%$ of mothers do not do vetting pregnancy even
$10.2 \%$ still saw a pregnancy in the shaman. Childbirth aid figures by the health workers is still below the national target, namely of $86.9 \%$, of which about $76.1 \%$ of pregnant women who give birth by health workers and $23.7 \%$ delivery still takes place in the home and rescued by a shaman, this is due to cultural factors and beliefs of society.

Papua provincial health Office profile 2014, shows that antenatal care services on a $\mathrm{K} 1$ of $56.3 \%$ and $\mathrm{K} 4$ of $34.48 \%$ it is still far from achievement of the national target of $95 \%$ i.e. $\mathrm{K} 1$ and $\mathrm{K} 4$ of $88 \%$. For service delivery by health manpower of $30.78 \%$ and service delivery by health manpower non of $59.22 \%$. It also has not met the national standard Labor coverage by health care personnel namely by $90 \%$.

One of the efforts to support the enhancement of the health of the mother during pregnancy is to provide care pregnancy and childbirth or during pregnancy antenatal services are carried out properly and as early as possible as well as placing a safe childbirth aid efforts to save lives of mothers as program priorities. The subject of death or pain on the real mother and son is inseparable from socio-cultural factors and the environment in the communities where they are located. Factors such as cultural beliefs and knowledge conceptionthe conception about the various dietary restrictions, the relationship between the causal food with healthy condition hurts, habits and ignorance often bring a positive impact or negative towards maternal and child health.

Study results Devy et al., (2011) about pregnancy care in Madura in the village of culture perfektif Embankment and 


\section{International Journal of Science and Research (IJSR) \\ ISSN (Online): 2319-7064}

Index Copernicus Value (2015): 78.96 | Impact Factor (2015): 6.391

village of Rapalaok sub-district of Sampang Regency Omben suggests that the influence of the culture surrounding the pregnancy is still robust enough so that they would believe those from culture at the urging of the health workforce. Pregnancy and childbirth care in cultural perspective advocated by families of pregnant women so that mothers did not dare to violate abstinence. In the process of labor they still choose shaman in maternity to midwife the birth process deemed hard and difficult.

Keerom Regency Health Office report of 2015, that in the area of Kanandega District Health Centers Waris to the achievement of the target service of antenatal care in pregnant women during the year 2013 - 2015 is quite varied. By 2013 there is as much as 181 people pregnant women antenatal services, as target of that number as many as 66 people pregnant women $(36.5 \%)$ who do $\mathrm{K} 1$ and 32 people pregnant women $(17.7 \%)$ who did the $\mathrm{K} 4$ while there are 2014 as many as 138 people as target pregnant women antenatal services, of that number as many as 64 people pregnant women (46.4\%) who do $\mathrm{K} 1$ and 53 people pregnant women $(37.7 \%)$ who did the K4. And by 2015 there are as many as 198 people pregnant women antenatal services, as target of that number as many as 70 people pregnant women (35.4\%) who do $\mathrm{K} 1$ and 40 pregnant women (20.2\%) who did the K4. When compared with the standard minimum service coverage of the visits of pregnant women (K1 and K4), is still very low. This shows the lack of antenatal service quality, because the national targets to be achieved for $95 \%$ of $\mathrm{K} 1$ and $\mathrm{K} 4$ of $88 \%$.

Achievement of the target scope of delivery by health workers who have the competencies of midwifery and childbirth deaths cases at Clinics Kanandega are also quite varied during the year 2013 - 2015. By 2013 there is as much as 181 birthing mothers, people from that number as many as 78 labor $(43.1 \%)$ are rescued by health workers who have the competencies of midwifery and childbirth 103 (56.9\%) who helped by non health. By 2014 there were 138 people, birthing mothers of these as many as 78 labor $(56.5 \%)$ are rescued by health workers who have the competencies of midwifery and childbirth 60 (43.5\%) nonpowered by 2015 while the health there are as many as 198 birthing mothers, people of these $113(57.1 \%)$ are rescued by health workers who have the competencies of midwifery and childbirth 85 (42.9\%) who helped by non health

The high relief giving birth by non health is a reflection of the existence of cultural influences that exist in society. Cultural influence in the practice of maternal health is also apparent on the shaman's involvement in the care of baby pregnancy, labor and childbirth. Study results Jahidin et al., (2012) shows that the value of social culture is the dominant factor affecting the election alternative birthing sando meana (shaman-child).

The preliminary results of the survey with the midwife Clinic Kanandega, said that most of the knowledge of pregnant women about pregnancy and childbirth care still are lacking, where the condition of the territory of the District of Waris still strong system embraced a culture that does not support the community to utilize healthcare, this led to the case emergency of midwifery can't be solved quickly and precisely, thus causing the death of the mother where the 2013 there are 2 cases of maternal deaths caused by the bleeding time and labor in January 2014 and 2015 there was one mother who died due to the infection of parturition.

The tribe is a community, Walsa settled in the Keerom Regency Waris district is majority society in General still trust the trust - a trust that is still growing in the life of the community. Walsa tribe live with the rules and values of culture are strong, they hold those values with her social life frame. Walsa tribe settlements far from medical services namely health centers Kanandega.

The tribe has its own view of the Walsa about pregnancy and childbirth care based on values that are adhered, where tribes Walsa have confidence that the death at the time of pregnancy and childbirth is a good death, so that efforts in handling the complications of pregnancy and childbirth need not be done excessively. When labor, usually pregnant mothers will be out of the House and living in small huts (demutpul) built in the forest as a place of birth, this is due to the belief that blood for men is very dangerous.

Viewed still a problem of maternal and child health among tribal societies Walsa and magnitude of the influence of cultural values in the treatment of pregnancy and childbirth is certainly very exciting to be researched. Although the study of pregnancy and childbirth care has been done, but the researchers want to do deeper research again on "the study of pregnancy and childbirth Care in the District of Papua Province Keerom Regency Waris(Ethnographic Study of the Walsa Tribe)".

\section{Method of Research}

The research design used in this study is a qualitative research design using Design Ethnography. Ethnographic research was aimed at outlining a culture as a whole i.e., all aspects of the cultural material that is both as a cultural artifact and the abstract nature of such experiences, beliefs, norms and value systems of the group that examined (Endraswara, 2012).

In this study, researchers want to examine in depth the treatment pregnancy and childbirth-tribes Walsa Keerom Regency Waris district in the province of Papua. The research was carried out in the District of Papua Province Keerom Regency Waris on the Walsa, with consideration of the Walsa tribe is one of the community who have a belief about pregnancy and childbirth care based on their understanding of hereditary. Where culture (attitudes, values, and beliefs) that cause the low coverage of the visits of pregnant women at health facilities (far from national standards where $\mathrm{K} 1$ and $\mathrm{K} 4 \mathrm{95 \%} 88 \%$ ) as well as birthing a aided by the shaman or the mother herself caused the low coverage of delivery by health manpower (much of the national standard that is $90 \%$ ). The time of the research was carried out on 18 August until November 26, 2016.

\section{Volume 6 Issue 7, July 2017 www.ijsr.net}




\section{International Journal of Science and Research (IJSR) \\ ISSN (Online): 2319-7064}

Index Copernicus Value (2015): 78.96 | Impact Factor (2015): 6.391

The discovery of informants in this study done by snowball sampling by using key informant was considered in depth can provide information about pregnancy and childbirth care Walsa tribe in accordance with the research objectives. Determination of key informant crucial in ethnographic research, where key informants is necessary to pave the way (gate keeper) researchers in touch with other informants, can also serve as the giver of the consent, the giver of data, ideas and spreaders of the provider (Endraswara, 2012).

In this case the researchers encountered a custom character as key informants, where indigenous figures will provide preliminary information is needed. To obtain information, researchers are looking for more information to Parties appointed by the indigenous tribes of the Walsa figures.

Informants involved in this research are pregnant and the mother of childbirth (mother descended from Walsa), families of pregnant women or mothers parturition (husband or parents of pregnant women or the elderly mother of childbirth), the midwife on duty in district of Heir Keerom Regency (which many know about the culture of care in pregnancy and childbirth on the Walsa), baby shaman (the person trusted and traditionally have skills in the care of the mother during pregnancy and at delivery) as well as indigenous tribes Walsa figures.

\section{Result and Discussion}

\subsection{The implementation and care of pregnant women}

Pregnancy care is the care provided to pregnant women with the objective of monitoring the progress of pregnancy to ensure the health of the mother and the growing fetus flower, improve and maintain the health of your physical, mental, social, mother and baby, to recognize the existence of early disorders as well as preparing for the role of mother and family in accepting the birth of the baby to be able to grow a flower normally (Saif,2009, et al.).

The results showed that the implementation of the care of pregnant women conducted by way of maintaining physical health with adequate rest, work as usual, maintaining hygiene, eating sparingly and interact with her baby.

The results of the interviews with informants, that maintain physical health pregnant women performed tribal Walsa with enough rest at night, work as usual with homework, keep gardening and maintaining healthy body by eating foods to taste that is adapted to economic conditions. Pregnant women also keep clean themselves with a regular shower, wash your hair and change clothes especially clothes in every bathroom runs out.

Keep clean themselves during pregnancy is very important, it can prevent the onset of diseases and infections. Sweat production in pregnant women become more sebasae glands, become more active and an increase in spending of pervaginam so that mothers are encouraged to change clothes in 2 times a day (Indrayani, 2011).
When the pregnancy continues, especially in the second trimester of pregnancy, the mother had started to adapt to her pregnancy. The nice thing of this period is the interaction with the fetus. According to the women of the tribe, there is movement of the Walsa baby when washing and cooking, the movement of the baby at the start of the left and right side of the belly of the mother. The mother usually does not count the number of movements of his baby, but according to the informant, the movement is very active and strong that it was felt the pain, therefore one way to eliminate such a sense to divert the taste.

Monitoring of fetal well being very important done by mum, this is to anticipate the danger signs of reduced fetal movement if in a day. Fetal movement monitoring at least performed for 12 hours. In addition to monitoring the movement of the fetus, during this trimester is also a good time to learn to communicate with "spirit baby" because it is essentially the inner bond between child and parents started in the womb.

The results of the interviews with informants, that in maintaining mental health during pregnancy, then the families provide support and suppor in the care of the mother's pregnancy. Support and given the husband starts from early pregnancy by observing the changes that occur in the body of the mother, the mother's support in taking care of her mother by banning heavy works such as crockery timber, timber or bring go into the garden. The husband also advised mothers to rest if feel tired.

The observations show that basically shaman and midwives also suggested the same thing, namely to reduce the heavy work, pay attention to the cleanliness of the body, diligently checked the pregnancy, taking medication regularly and visit the health worker if the mother's health is compromised. Although pregnant women are recommended to avoid things that can be dangerous for her pregnancy, but there are still pregnant women who ignore the advice. Based on the observations, there are still pregnant women who do activities in the garden at the time husband of pregnant women are not at home.

The habit to work in pregnant women for some tribes of the Walsa is a commonplace thing to do. For women, the body moves the Walsa tribe while pregnant will increasingly facilitate the birthing woman. Most tribal women Walsa, not too concerned at the occurrence of a thing that can be fatal in its content. Real physical activities that are heavy on while pregnant is very dangerous to the baby was conceived.

Activity that require heavy physical labor, will produce great energy so it will be able to reduce the calories available to the fetus, while the necessary energy needs most drained by the work being done by the mother. Insufficient energy needs in pregnant women with heavy work like this is one of the factors that may affect birth weight babies that will be born (Yuliva et al., 2009). Concern that continued during pregnancy or when mom approached labor, then physical activity performed female tribe Walsa as to the grounds must be reduced so that more mothers focus on the preparation of childbirth and regain power.

\section{Volume 6 Issue 7, July 2017 www.ijsr.net}




\section{International Journal of Science and Research (IJSR) \\ ISSN (Online): 2319-7064}

Index Copernicus Value (2015): 78.96 | Impact Factor (2015): 6.391

Pregnancy is a time when the body of a pregnant woman undergoing physical and psychological changes due to the increase in hormones during pregnancy. Hormonal changes experienced by pregnant women will lead to the occurrence of change in emotion and bring up some reactions among others a happy, sensitive, easily offended, disappointed, sad, anxious even stress.

According to the informant, in the period of pregnancy, the women of the tribe Walsa often feel anxious, worried even afraid of the circumstances of their subjects. Feelings of anxiety often experienced when signs of pregnancy yet surely found. Besides feelings of anxiety also appear when the mother felt the early symptoms of pregnancy where there is nausea and vomiting during pregnancy. Anxiety and fear are rising at a time when moms feel fetal movement is lacking.

Research conducted by Aprianawati and Sulistiorini (2011), that during pregnancy the mother felt anxiety in accordance with the stages of age of her pregnancy. According to the informant, support is provided to reduce the anxiety of the mother's husband is husband's involvement with since the beginning of the pregnancy and give you inner peace so as to reduce anxiety in the mother.

Family support is especially very useful in controlling husbands of pregnant women against the anxiety level and may also reduce the pressures that exist on a conflict that happened to her. Family support may be empathy, motivation, encouragement or assistance that can make expectant mothers feel more calm and safe, satisfied and will affect the welfare of the inhabitants of pregnant women. With the support provided, also will develop the belief that pregnant women that loved and cared for.

Pregnancy is a great happiness for a female, happiness is often communicated to others especially the husband, but the women of the tribe Walsa, this should not be done. Research results that at the beginning of pregnancy, women tribe Walsa will not deliver her pregnancy to her husband. Usually the husband will know their own pregnancy of his wife after she had passed the third month or husbands see their own changes that occur in the body and the face of the mother.

The tendency of cover pregnancy is done mainly at the beginning of pregnancy (the age of the content of 0-4 months). The Customs and culture of the tribal women firmly Walsa since ancestors, tribal women Walsa reject to inform the early pregnancy to your family especially the husband himself.

\subsection{This type of Examination in pregnancy make pregnant women}

This type of examination is utilized pregnancy options specified in checking her mother conducted periodically from early pregnancy until childbirth process to monitor the health of the mother and fetus so that achieved optimal pregnancy. Pregnancy examination can be done in the health workers through the obstetrician or midwife with a minimum of 4 times the examination during pregnancy (Kusmiati, 2010).
The results showed that the women pregnancy examination, Walsa tribes traditionally done by utilizing the services of a shaman that exist at each of their hometown. The women of the tribe making Walsa shaman as an option in checked her pregnancy. Examination of pregnancy by using the quack's services is done at the time the Walsa tribe women aged 2 through 9 months of pregnancy

According to the women, the reason for selecting the Walsa tribal shaman because shaman capable of knowing the signs of pregnancy the mother by just looking at the changes that occur in the body of the mother as well as a shaman is also capable of knowing the position of the baby in the stomach just by holding the belly of the mother without using any tool. Find pregnant women, herbalists will give advice on the mother to maintain pregnancy the mother with the rest if the mother is tired.

Research of Astriana (2012), shows that in general the pregnant women, in addition to routine pregnancy checked at posyandu also use the services of traditional birth attendants in both pregnancy care or help labor. According to them it will be easier to give birth in a quack if labor time has come because other than baby shaman knows the age of the content through the sort (massage) when the first month and through massage baby Shaman can fix the position of the fetus or the problematic content, in the next months as felt pregnant women generally so easy a baby was born.

Research conducted by Suryawati (2007), shows that there are still many communities who need baby shaman. Baby shaman also ready any time needed, giving a sense of comfort and secure because they are mostly elderly women, as well as family relationships create a presence in baby shaman certain things difficult was replaced by a midwife. It cannot be denied that often, because of failure to meet health programs a try to run just solely by technical considerations based upon the medical ' stiff '. One program that has not yet reached target as expected is the examination and aid delivery. Almost all over Indonesia is still much pregnancy examination conducted traditionally similarly help labor.

According to Laila and Triratnawati, (2010) baby shaman or midwife, also known as the village, is a woman of her age is quite old (50-70 years) and they've not regenerates so labor is able to help others. As a helper in childbirth, Shaman favoured than medical helper. The reason the community choose shaman based five factors i.e. experience, tradition, psychology, economics and condition of pregnancy.

Baby shaman in the treatment of pregnancy women Walsa Tribe, still utilized by citizens of hereditary. This habit has become a tradition that is carried out on an ongoing basis until today. The role of the shaman in the treatment of pregnancy women tribe Walsa very Extras, where shaman voluntarily will make a visit to the home to check the mother's pregnancy.

Setiyawati and Gita (2010), suggests that very trusted shaman among the local community as an actor and as a key figure is primarily related to health and safety. In the case of childbirth, shamans not only acted when this process takes

\section{Volume 6 Issue 7, July 2017}




\section{International Journal of Science and Research (IJSR) \\ ISSN (Online): 2319-7064}

Index Copernicus Value (2015): 78.96 | Impact Factor (2015): 6.391

place, but also upon the customary rites believed to bring safety for the mother and her seven events such as monthly pregnancy until 40 days after the birth of a baby.

In addition to the examination of pregnancy by using the quack's services, there are also women of the tribe Walsa utilizes the services of health care personnel (midwives). The women of the tribe saw her pregnancy will Walsa to health workers (midwives) if the content is already big or step on the 5th of the month or when there's been a real change on the part of the stomach (abdomen enlarged mother) and already felt the movement of the fetus. This is causing the low coverage of the visit of the $\mathrm{K} 1$ (contact the first expectant mother in the first trimester) to health workers.

Still the low coverage of antenatal care services, due to the cultural order which influence in the decision saw a mother in pregnancy on the health workforce besides a State family environment that does not support will affect the mother checked in her pregnancy. Research Halim et al., (2014) in Nepal showed that family support is primarily a husband is a factor that affects pregnant women antenatal care services to take advantage of. Therefore the role of the family in antenatal services is very important. The family as the person closest to the expectant mothers have to motivate mothers to checked her pregnancy. Family support against pregnant women can be pointed out with Usher's mother checked her pregnancy and pregnancy Checkup schedule constantly reminds mothers.

Antenatal care services aimed at lowering the number of pain and death of the mother with the efforts of midwives monitor the progress of pregnancy in an effort to ensure the health of mother and baby development normal. When pregnancy examination at midwife, Walsa tribe women will get the services in accordance with the standard inspection of the pregnancy. The actions that are performed when a midwife provide pregnancy among others by measuring blood pressure, measure the circumference of your upper arms, weigh, giving the drug to add blood and drugs kalk to bone growth of the baby. Besides midwives also provide guidance about the treatment of the mother while pregnant where mothers are encouraged to enough rest, eat balanced food with nutrition and diligent of pregnancy checked regularly.

As a fact, for informants in interviewed recognize that pregnancy examination they did have an impact on their health condition prior to their baby. Through examination of the pregnancy, they can control their gestational age based on considerable help in interpreting the question of when he will deliver later. In addition through an examination of their pregnancy benefit that they gain knowledge about the importance of consuming vegetables that have contributed to the prosperity of their fetus.

In addition to pregnancy examinations by utilizing the services of traditional birth attendants and midwives, there are also women of the tribe completely Walsa never did pregnancy checkup. The reason the mother is not checked her pregnancy because the mother did not realize if it actually was pregnant so that the mother stays busy by gardening activities. The mother said her son since the birth of the last,

he did not get a menstrual period every month like a normal woman that he did not know if pregnant.

Yogaswara research (2011), shows that pregnant women who are not healthy does not stand on its own, all is a result of the fundamental causes such as poverty, the poverty of the said knowledge of pregnant women and families about how to keep the pregnancy the mother so munculah such unhealthy behavior of pregnant women is not in contact with health workers and not checked her pregnancy.

Health efforts should be done early on in order to prevent diseases and conduct early detection against the gestational mother and an attempt is made at the time, this is where the importance of the role of the midwife as health workers in providing information about antenatal care so that will help pregnant women to obtain better information

\subsection{Diet Pattern and harm diet of pregnancy.}

Diet is a way or a behavior that is a person or a group of people to vote, using foodstuffs and food consumption every day that includes a number of types of food, food, food frequency, based on factors of social culture in which they live (Hariyani, 2012).

According to the informant, that pregnant women have an eating pattern of Walsa tribes with the same pattern of feeding his family, pregnant women eat $1 / 2$ to 1 serving platter spent with frequency 2-3 times a day mother with main menu papeda (made from sago) eaten with vegetable or fish if there is food consumption, but pregnant women are very limited. The mornings are usually pregnant mothers only consumes bananas, cassava or Yam, taro and steamed in the fuel, the daytime pregnant women eat papeda and vegetable, as well as in the evening. The consumption of vegetables such as spinach, vegetable vegetable vegetable and gedi cassava, vegetable this in sports by the way in a stir-fry or stew. Observations menu that is served is not so much the form of the terhidangkan.

The results of this research show that the informant still less understand that during pregnancy need special attention in the diet. Not a good diet will cause the nutritional intake of pregnant women would be sure not that can endanger the mother and the baby, because the relationship between the health of mothers and babies conceived are very closely, where the baby was conceived health depends on the health of the mother.

Promotion of the importance of a balanced menu while pregnant is one of the efforts in preventing the occurrence of health problems in women Walsa tribe. During pregnancy, the mother is required to pay attention to the principles of the food patterns i.e. number of more, better quality with a menu tree must be balanced, namely foods containing energy sources, animal products, vegetable and fruits. In addition pregnant women should also consume food that varies as foods containing iron, vitamin $\mathrm{A}$, calcium, magnesium and vitamin $\mathrm{C}$ which can meet the nutritional needs during pregnancy.

\section{Volume 6 Issue 7, July 2017 www.ijsr.net}




\section{International Journal of Science and Research (IJSR) \\ ISSN (Online): 2319-7064}

Index Copernicus Value (2015): 78.96 | Impact Factor (2015): 6.391

Food abstinence or prohibition is a taboo to consume a certain type of food because there is a danger of threats against anyone who violated that, under the threat of danger is the megis impression namely strength superpower that smells of mystique that would punish people who violated the restrictions or taboos (Sukandar, 2010).

The results showed that during pregnancy, there are some foods which became the tribal women of abstinence Walsa where they shouldn't be eating food from the animal like a rat, ground meat, kangaroos cassowary tree land, crocodiles or soa-soa and chicken eggs. As a result of a violation of these restrictions may cause bleeding during childbirth or after the baby is born could happen a fatal breathing disorder which can cause death in infants. Mom also never eat the tortoise and turtle, if pregnant women breaking the restrictions could lead to children born in the State of the feet and hands.

Other dietary restrictions mother should not eat kus-kus black trees because it can prevent a baby cannot be born, childbirth causes long until mother died. Fish Cork, nine fish, birds taon-taon Partridge eggs and also the food abstinence pregnant Walsa tribe. Fish fish Cork and nine tribal beliefs and customs according to the Walsa, when pregnant women eat these foods, can lead to children at large is not settled and will in the village to wander far from the village of his birth. Taon-taon bird feeder can cause a child not be stepped up quickly and its too late.

Many types of harm food of the animal (tree kangaroos, tortoises/turtles, fish, Cork nine and junglefowl eggs) of the said foods that contain iron the hem that is derived from iron haemoglobin and Myoglobin. Iron on animal food higher absorption i.e. 20-30\%, while of vegetable source only 1-6\%. The research of Bahar (2010), chicken eggs are naturally nutrient-rich capsule i.e. iron, phosphorus, calcium, sodium and magnesium. More eggs nutritional source on the yellow eggs, so abstain eggs while pregnant harm health.

In addition to the restrictions against food from the animal, there are also eating vegetable of abstinence like the mother should not be eating coconut, vegetable wax/vegetable feathers if consumed could cause the lips and mouth injuries. Mom also never eat cucumbers, bananas and sweet in a long time because the child after birth could be exposed to the diseases of lymph. A large pumpkin, kasbi yellow and sago are no thorns if eaten will have an impact on the process of childbirth where maternity mother will get a lot of problems to cause the mother's death.

Bananas contain enough vitamin A, vitamin B1 and vitamin $\mathrm{C}$ as well as make a donation simply means a mineral like calcium, phosphorus and iron. The kinds of the vitamins needed for the absorption of $\mathrm{Fe}$ in the intestine and move it into the blood, was also involved in the mobilization of deposits of hemosiderin in the nodes mainly Fe.

Abstinence is abstinence of the Act not to do pregnant women i.e. Walsa tribe of pregnant women are not allowed to drink water of a well or pass through the Lake because it is believed can cause the baby would die in the womb or after birth her baby would die.

Beliefs and dietary restrictions-restrictions against some food will certainly cause conditions of mother loss of nutrients. Meanwhile, their daily activities are not coupled with diminished dietary restrictions-restrictions against some of the food is actually very needed by pregnant woman certainly will negatively impact the health of the mother and the fetus. According to the Treasury (2011), it can be said that the question of the restrictions or taboos in consuming certain foods there are universally around the world. The restrictions or prohibitions is such a taboo to consume a certain type of food, because there is a danger of threats against anyone who break them. In the threat of danger is a magical impression, that strength superpower that smells of mystique that would punish people who violated the restrictions or taboos. It seems that the various dietary restrictions or taboos was originally intended to protect the health of children and the mother, but this goal even result in adverse conditions, i.e., instead of nutrition and health.

The conception of the cultural community regarding abstinence is intended to maintain the safety of the baby and the mother. But the reasons put forward regarding the behavior of abstinence is often not a logical nature, and partly reflects the association between species of plants or animals that are restrictive with conditions or the consequency predicted that its nature associative. So in this case the need to outreach on the importance of the fulfilment of health nutrition for pregnant by increasing consumption of foods containing animal protein sources, so that it can help increase the intelligence of the brain on the fetus in the bladder, and prevent the high number of anaemia in pregnant women.

\subsection{Helper and handling labor by non medical personnel}

Childbirth care is care given to mothers ahead of labor until labor walked in an attempt to achieve a clean, secure delivery with the aim of maintaining the viability and provide a high degree of health for the mother and her baby (Rukiyah et al., 2012).

Direct election of the influential cultural power helper in childbirth, because general conditions of pregnancy and childbirth are interpreted differently according to different cultures. Helper in childbirth are ordinary people who examine pregnant women or provide help during labor. The results showed that associated with childbirth in women tribal helper Walsa is a person who assists in childbirth, childbirth is usually done by the mother alone or shaman and assisted relatives/family or mothers close to home. If the labor trouble, then women will call the midwife Walsa tribe.

Based on the results of the interviews, that the women of the tribe Walsa is familiar to help himself in the process of childbirth. Childbirth experience before with the number of children over 5 people, which bore no problems in the process of labor made women feel capable Walsa tribes to give birth themselves. For women of the tribe, gave birth to its own Walsa is a tradition they have done since long ago

\section{Volume 6 Issue 7, July 2017}




\section{International Journal of Science and Research (IJSR) \\ ISSN (Online): 2319-7064}

Index Copernicus Value (2015): 78.96 | Impact Factor (2015): 6.391

and it was hereditary. Childbirth itself is a pride and respect in the tribal customs of the Walsa.

According to the experts that a woman could have given birth to her baby on its own without the assistance of another person or without involving health workers if everything under normal circumstances. This means that there are no complications or risk factors as well as the mother and her baby in a healthy state. In the condition of pregnant mothers who don't have the disease, a baby who is born is not too big as well as have knowledge of how do I cut the umbilical cord, and must use sterile instruments. After the baby comes out, then the placenta from the baby will also be out and sometimes the placenta it can uninstall itself. Women who give birth should also ensure that bleeding does not occur.

In addition to giving birth to yourself, there are also women of the tribe of the Walsa childbirth assisted by traditional birth attendants or nearby family who have had the experience of giving birth before. As a helper in childbirth, Shaman favoured than on health workers (midwives), Walsa tribe reason women choose shaman as a helper persalinannya based on 3 factors, among others, experience, psychology and the condition of pregnancy. The experience factor is perceived by most informants because they have regular childbirth with a quack additionally has a working period 2333 years. The length of the period of employment and experience possessed shaman in helping labor will cause someone's interest to keep selecting them. In addition to this shaman in helping labor through a natural way, they did not take any action unless the umbilical cord cut by using a razor blade.

Psychological factors of perceived benefits by the mother because the shaman provides convenience and quick if on call. In addition with the shaman's mother feel calm and comfortable while giving birth. The nature shaman who Frank Burton Cheyne and willing to keep good afternoon or night, also brought positive influence on his reputation. The shaman has a strong charisma in society, they are considered as a wise old man and is able to dive into the heart of the local community. In addition to social support provided as well as the massage of shaman done at a time when labor pains occurred can reduce pain so that the State is able to evoke a sense of comfort in the mother. The proximity of the relationship between the shaman and the mother either personally or through social and cultural similarities form the consolation of a sense of community is strong so as to provide a sense of comfort in the mother.

Another reason most informants felt shaman election because a healthy body condition and it is believed not to be complicated at the time of birth. The informant said the reason normal pregnancy conditions because they do not feel there are any symptoms beyond the habit despite the informant who gave birth to 36 years of age above where the age is at high risk of giving birth.

Prepare pregnant women face birth labor is a very important part of a pregnant woman at the end-the end of her pregnancy. As with preparing everything that relates to the preparation before giving birth would be very influential in the course of the process of the birth of a baby and the mother's health and also protected of the baby later. It is no exception with the women of the tribe Walsa, while labor, they will prepare for childbirth. Preparation is carried out, among others, preparing baby equipment and supplies.

According to the informant, the prepared baby gear consists of clothes, talc, baby diapers, cloth pads and a razor blade to cut the umbilical cord. While the requirement for the mom who prepared, among others, clothing, woman, underwear, mat/tents and hot water in a plate who will be used to clean the baby and mother are also used for bathing after childbirth.

No less important, the women of the tribe Walsa also prepared leaves of itching. True to its name this leaf gives rise to effects of itching when in contact with skin. When Burr on the surface of the leaves touching the body, the widening of the pores on the skin that stimulates blood circulation giving rise to a sense of warm in the skin. According to the informant, leaves this itching will be used when the mother felt the pain by means of rubbing on the side of the abdomen to the left and right also in bones of the back.

When the leaves are rubbed, hives for the first time the skin will itch, get carded, the itching will disappear by itself. In view of the Walsa tribe, leaves the itch is said to have first aid at a time when moms feel pain, benefits from the leaves of the itch is to reduce the pain when giving birth and gives a sense of warm in our body.

Leaf itch that has the latin name Laportea decumana, utilized as traditional medicinal plants and sold in traditional markets in Papua. Plant "leaf itch" it generally does have chemical contents such as monoridin, tryptophan, histidine, alkaloids, flavonoids, formiat acid and authraguinones. Ant acid itself is contained in the ' thorn ' on the surface of leaves. When the ' thorn ' on body in the Ant acid, it release and affect the onset of dilation of pores - porous body. This pore pore dilation apparently stimulate the blood circulation. That is why leaves users itching generally feel sore - they disappear or feel better. Itchy leaves encountered in the land of Papua, thrives in the wild. The community use to treat the itch leaves Achy all over body parts.

Related to the birth companion, now unlike the past, when the husband is not allowed to witness the birth of his mate. They are considered a nuisance that may be faint and if any are allowed in, his role merely as spectators only. The attitude and practice of the obstetrics in developed countries has changed a lot after a few decades, and now the husband is regarded as part of a labor. Now a growing number of husbands who attend tutoring antenatal and childbirth in space attended armed with knowledge as well as his partner. They want to be present, not only to watch but also share their experiences and help as much as possible in the process of childbirth.

With allowing husband is present in the birth, then the relationship of mothers, fathers and their babies will be more firmly established. Involve the candidate's father early on

\section{Volume 6 Issue 7, July 2017}




\section{International Journal of Science and Research (IJSR) \\ ISSN (Online): 2319-7064}

Index Copernicus Value (2015): 78.96 | Impact Factor (2015): 6.391

since the process of pregnancy is very meaningful to the husband of the mother. And togetherness that were formed since the time of pregnancy will help it understand the process of the birth of a baby in the future and prepare it to become a father.

According to Nurasiah et al., (2012), that the presence of a companion in labor can provide a sense of comfort, safety, morale, emotional support, and can be encouraging mother. The presence of a companion in labor over his own choice is one of the recommendations in the manual maintenance of normal births. Some mothers choose a spouse and mother to become advocates of the birth.

But not with the Walsa where their cultural customs if the husband to accompany his wife when giving birth. In labor, husband not allowed to accompany the wife, the husband's involvement is only done in preparation for labor as it prepares a place for mothers in labor and call your nearest family when wife shows signs of labor. Next husband will be at home next to or live in another family home. According to the informant, the husband not to be close to his wife when the labor lasted until 3 or 4 weeks after the baby is born.

According to tribal customs and beliefs of the Walsa, blood of women during childbirth is the dirty blood if inhaled by a husband, can cause a runny nose, cough affected husband and hosa (shortness of breath), health is impaired and the old fast.

The Walsa tribal women will give birth, it will be made a separate room custom to give birth to her baby. The room was set aside for women when they are in the course of their femininity (menstruation) and three to four weeks after the mother gave birth to her baby. According to the informant, while labor, women tribe Walsa will bear didapur, back rooms or in the cottage that has been prepared or built specifically by her husband. The cottage was built not far from the parent's home, just a few metres away from the edge of the House. The shape of the building is not so different from the main house only smaller.

In terms of culture, spawned not only is a process that not only solely with regard to the birth of the baby, because at the time of the mother's womb out also the elements that are usually categorized as dirty items such as blood, amniotic water, umbilical cord and placenta. In terms of culture, the notion of ' dirty ' is not always refers to literally, but dirty in the sense of ' earthly ' as opposed to the nature of the sacred, Holy and ghoib. Here explained that the views of the public about clean area that should not be littered, while giving birth is the process of discarding dirty elements so that the choice of giving birth to female tribe Walsa set in the kitchen, the back rooms or cottages special. Although at the present culture has undergone a change, but women still run custom Walsa tribes bore based on those concepts (Koentjaraningrat, 2009).

Many women start to feel the signs and symptoms of Labor a day even a week before the baby is actually born. These signs tell you that labor is near, and helps the body prepare for motherhood. If the mother gave birth for the first time, signs of early labor can occur several weeks before labor. As for the next pregnancy, these signs may be felt when it was nearing labor.

Informants in this study reveals that every woman would give birth to the Walsa tribe has a feeling it will be a time where they have to bear. With their ability to read the sign will bear, what purposes they will soon be filled. Through the reading of a sign, women tribe Walsa put myself to be more relaxed so as to allow their healthy thinking in the process of childbirth. The results of research that, signs of childbirth on women Walsa tribe began with soreness and pain. When the aches and pains that women will use the Walsa tribe leaves itching to reduce pain.

Associated with the position of the time will give birth, usually female tribe Walsa will take the position of the squat which makes their childbirth. The position of the squat while giving birth i.e., sitting on a mat/cloth tent or dialas, with both hands on the rope of mother that has hung above the pillar room/cottage or with pole position sitting leaning on the wall/rests on the body of another woman while both hands hold the knee to the left and the right.

The women of the tribe Walsa stated that a baby who indeed are at a good position, then he will constantly as if "dropping" himself. That knowledge then believed the baby will come out by itself would be easier if the mother in the position of the squat.

Actually there is no position bore the most good. Position the felt most comfortable by the mom is the best thing. There are several positions of the mother during childbirth, namely: (1) Litotomi Position (lying down), is the most common childbirth positions in Indonesia. Expectant mothers are asked on her back with the second legs drape on the cantilever exclusively for maternity. His advantage psychologically, makes the mother feel better because that is in the position of bearing its perception is indeed like that, this position make doctors or midwives feeling free to help labor because the road was born forward-facing. (2) the position of the squat, is advantageous position because of the influence of gravity, the mother's body does not have to be stronged struggled, the baby will come out through the street born by itself. The drawback, namely when not prepared properly, the position of the squat very likely made the baby's head injuries, because the baby can "slide" quickly. (3) position of the Half sitting, this position requires that the mother sitting with your back leaning against the pillows, legs bent and her thighs opened towards the side. The benefits of this position makes the mother feel comfortable, wicks road born who need to get it out is shorter, the supply of oxygen from mother to fetus takes place optimally. The drawback of this position could lead to complaints of sore in the back and fatigue, especially if the process is persalinannya long. (4) position of the Lateral (Italics), this position requires pregnant mothers lay tilted to the left or to the right. One foot is lifted while the other leg straight in the State. Wont to do when the baby's head position is not yet right. This position can also be used when labor last long and the mother was already exhausted by the position of the other. The benefits i.e. blood vessel behind the mother flows smoothly, delivery of oxygen in the blood of the mother to

\section{Volume 6 Issue 7, July 2017}




\section{International Journal of Science and Research (IJSR) \\ ISSN (Online): 2319-7064}

Index Copernicus Value (2015): 78.96 | Impact Factor (2015): 6.391

the fetus through the placenta are not bothered because not too pressing, the process of opening takes place slowly so that labor relatively more comfortable. The drawback of this position keeps the doctor or midwife little difficulty helping birthing, infant head harder held or redirected, when having to do any position more difficult episiotomy (Rukiyah, et al., 2012).

Associated with breathing techniques while giving birth, this research shows that the women of the tribe will regulate Walsa breath as much as two to three times after that will push the baby out by the way might still persist. A good breathing techniques by means of a long breath and exhale slowly thrust was accompanied with the most important things conquered. Custom tribal women Walsa to remain active despite the pregnant helps them keep their respiratory conditions to remain stable.

Straining is a technique that needs to be known by every mother who give birth, in essence they are required to know how the connectedness between the movement of the baby in the stomach with an urge of breathing. With the encouragement of balanced, a tear in the street of birth will not occur. setting a good breath won't make the road was born into a tear. There is a conviction of the women of the tribe that the Walsa (vagina) is an elastic thing and certainly will be back in its original condition. Therefore they are not too concerned at the way the tear was born.

There is two basic breathing for labor such as slow breathing or mild respiratory and breathing. During labor to help relaxation and assure adequate oxygen supply can be done by changing the respiratory response to the intensity of the contractions. Slow breathing is a long breath, calm down and slow focusing directly the mother on what happens to the babies and help in every contraction.

After the baby is born, soon followed by the birth of the placenta commonly referred to with her brother's baby. For cutting baby's cord, usually done using a razor blade. Razor blade used is a new razor blade before use dipped first in boiling water to kill germs. What is done by the women of the tribe Walsa done so extra careful because other cord connected with children.

In the childbirth process Walsa tribe cuts the umbilical cord of the baby after the baby's placenta comes out, it is believed on pregnant women there are two lives in the belly of the mother that is the life of brother (placenta) and the life of sister (baby), so in order to not be left behind in the placenta, umbilical cord then it should not be decided before the baby came out. The utterance of the informants in this study, after the baby is born is usually followed by the birth of a brother (placenta), after that it can be done cutting the umbilical cord. After cutting the umbilical cord, the tribal women Walsa would tie the umbilical cord has been cut by using a rope to avoid bleeding occurs noken on baby's cord. In addition to using rope noken, there also are using yarn to sew the fabric.

According to POGI, et al (2010), the umbilical cord is the life line of the fetus and the baby for a few minutes after the first birth. The separation of a baby from the placenta is carried out by means of clamping the umbilical cord between two clamps, with a distance of about $8-10 \mathrm{~cm}$ from the umbilicus. The cord should not be cut before making sure that the cord was clempt well. The failure of such action may result in the expenditure of excess blood from the baby.

The results of the interviews with informants that, tribal women care the placenta has a tradition of Walsa way buried in the ground. There is a belief from them that the Centre and the placenta is a counterpart of the children born to it should be kept too well. In the Council, the placenta will be washed first so completely clean, and then inserted into pockets of pastic, then put again into the bay and was buried in the soil.

Placenta burial process performed by the women of the tribe Walsa as biological mother, sister or younger sister who helps the process of childbirth. Placenta burial was done in accordance with the position of the home that unoccupied. If the house occupied a high position (stilts), then the placenta burial was done in the space under the House. But if the house occupied the flat position, then the placenta burial can be done on the side of the House, near the pillars of the Kings.

Umbilical cord himself will dry up within a week and fall by itself. There is no special treatment for the rest of this cord. The women of the tribe Walsa generally let the cord dry naturally.

Labor is basically not in spite of the risks of hemorrhage or death. It most certainly needed maturity and courage. In the tradition of the indigenous tribal communities Walsa, when a mother cannot or difficult childbirth, they had the belief that while pregnant mother violate abstinence-abstinence or the mother got interference from outside such as affected by evil spirits or artificial people who were not happy with the family.

If bleeding occurs when the mother gave birth or after birth the baby or the mother dies, it is because the mother violates the restrictions or prohibitions or man-made, due to action or spirit ancestors until the death of the mother when giving birth to the Walsa is a thing that doesn't need to be questioned.

Still in pain and the high number of maternal deaths in Papua Province due to bleeding, infection, eklamsi, the complications and old delivery abort, besides factors lack of information, poverty and ignorance of men against reproductive health. So men are expected to participate in the improvement of women's reproductive health efforts by planning a safe delivery by medical personnel.

The misfortune that befell mother due to lack of knowledge and lack of assistance services should be a right of reproductive health was considered reasonable due to the faults of his own. This principle makes women marginalized Walsa tribe. Therefore trust that perceive that the deaths of women during childbirth Walsa tribe was the death caused due to man-made, to action or spirit ancestors need to be revamped so that the women of the tribe Walsa getting

\section{Volume 6 Issue 7, July 2017}




\section{International Journal of Science and Research (IJSR) \\ ISSN (Online): 2319-7064}

Index Copernicus Value (2015): 78.96 | Impact Factor (2015): 6.391

attention from society because every woman deserves to get health services and adequate protection for the health of the said reproduction to avoid death from childbirth.

The results of the interviews with informants that, treatments performed by the women of the tribe Walsa after childbirth include cleansing the body and clean the peralataan which had been used when the birth mother istrahat after that. Walsa tribe women will wait until the blood from the street was born out, then they will cleanse the body by way of the bath or the melap Agency by using warm water which has been prepared at the moment ahead of the birth.

After cleaning the body, women tribe Walsa will rest a moment to recover the power that has been used when giving birth. If the baby is crying, then women will breastfeed her baby Walsa tribe. Post-birth women Walsa tribe usually eat soups and vegetables papeda like vegetable gedi that can quickly heal wounds after delivery, expedited the process of spending blood and breast milk.

\section{References}

[1] Alwi 2011. Aktivitas Sehari-Hari, Pola Makan Dan Perilaku Pencarian Pengobatan Ibu Hamil Dan Nifas Suku Kamoro Papua. Jurnal Kesehatan Reproduksi, Volume 1 No 2 April 2011, 73-83.

[2] Agussalim, Josephine Lorica .2016.Cross-cultural adaptation and validation of the cultural self_efficacy scale for Papua Nurses. International Journal of Science and Research, Volume 5 Issue 6, June 2016.

[3] Burhanto. 2013. Konsep Sehat Sakit Ibu Hamil Pada Etnis Kutai Di Desa Teluk Muda Kecamatan kenohan Kabupaten Kutai Kartanegara. Thesis Program Pasca Sarjana Universitas Hasanuddin Makassar.

[4] Devy, Haryanto et all 2011. Perawatan Kehamilan dalam Perspektif Budaya Madura di Desa Tambak dan Desa Rapalaok Kecamatan Omben Kabupaten Sampang Jurnal Promosi Kesehatan Indonesia, Volume 1 No 1 Maret 2011, 50-62.

[5] Dewi \& Sunarsih, T. 2011. Asuhan Kehamilan Untuk Kebidanan, Jakarta, Salemba Medika.

[6] DINKES 2015. Profil Kesehatan Propinsi Papua.

[7] Dumatubun, A. E. 2002. Kebudayaan, Kesehatan Orang Papua Dalam Perspektif Antropologi Kesehatan. Jurnal Antropologi Papua, Volume 1 No 1 Agustus 2002, 1-33.

[8] Endraswara, S. 2012. Metodologi Penelitian Kebudayaan, Yogjakarta, Gajah Mada University Press.

[9] Harahap, J. R. 2011. Pengaruh Ketimpangan Gender Dalam Keluarga Dan Karakteristik Ibu Terhadap Anemi Dalam Kehamilan Di Wilayah Kerja Puskesmas Rumbio Jaya Kabupaten Kampar. Tesis Fakultas Kesehatan Masyarakat Universitas Sumatra Utara.

[10] Indrayani 2011. Buku Ajar Asuhan Kehamilan, Jakarta, CV. Trans Info Media.

[11] Indrayani \& Djami, M. E. U. 2013. Asuhan Persalinan Dan Bayi Baru Lahir, Jakarta, CV.Trans Info Media.

[12] KEMENKES. 2013. Angka Kematian Ibu Jakarta [Online]. Available: http://www.kesehatanibu.depkes.go.id/ [Accessed 20 Februari 2014].
[13] Mayasaroh, R. 2013. Peran Dukun Bayi Dalam Penanganan Kesehatan Ibu Dan Anak Di Desa Balo Kecamatan Demak Kabupaten Demak. Solidarity: Journal of Education, Society and Culture 36-44 (http://journal.unnes.ac.id/sju/index.php/solidarity).

[14] Morin, D. D. 2013. Seri Etnografi Papua No 2 Budaya Dan Kesehatan, Jayapura, Central For Melanesia Studies University Of Cendrawasih.

[15] Morin, D. D. \& Mansoben, J. R. 2013. Seri Etnografi Papua No 1 Kebudayaan Masyarakat Papua, Jayapura, Central For Melanesia Studies University Of Cendrawasih.

[16] Nuraeni, S. \& Purnamasari, D. 2012. Perilaku Pertolongan Persalinan Oleh Dukun Bayi Di Kabupaten Karawang. Jurnal Seminar Nasional Kesehatan 31 Maret 2012

[17] Rahmawati, I. 2012. Hubungan Tingkat Pengetahuan Ibu Hamil Dengan Pencapaian Cakupan K4 Di Puskesmas Sawahan Surabaya. Jurnal Media Informasi Ilmiah Volume 1 No 1 Agustus 2012, 1-12.

[18] Romauli S. 2011. Asuhan Kebidanan Pada Kehamilan, Yogjakarta, Nuha Medika.

[19] Setiyawati \& Gita 2010. Modal Sosial Dan Pemilihan Dukun Dalam Proses Persalinan : Apakah Relevan ? Jurnal Makara Kesehatan, Volume 14 No 1 Juni 2010, 11-16.

[20] Sukandar, D. 2010. Makanan Tabu Di Rokan Hulu Riau. Tesis Gizi Masyarakat Universitas Sumatra Utara.

[21] Towodros, A, M. G. \& Dibaba, Y. 2009. Faktors Affecting Antenatal Care Utilization In Yem Special Woreda, Southwestern Ethiopia. Ethiop Journal Health Sci, Volume 19.

[22] Tura, G. 2009. Antenatal Care Service Utilization And Associated Faktors In Metekel Zone, Northwest Ethiopia. Ethiop Journal Health Sci, Volume 19.

[23] Wahyuni, S., Thaha, R. M. \& Suriah 2013. Konsep Perawatan Kehamilan Etnis Makassar Di Kabupaten Jenneponto. Jurnal Fakultas Kesehatan Masyarakat UNHAS.

[24] Yenita, S. 2011. Faktor Determinan Pemilihan Tenaga Penolong Persalinan Di Wilayah Kerja Puskesmas Desa Baru Kabupaten Pasaman Barat. Tesis Pasca Sarjana Ilmu Kesehatan Masyarakat Fakultas Kedokteran Universitas Andalas Padang.

\section{Author Profile}

Susana Ramandey has a basic education as a midwifery then continued her master in Public Health. She has worked as a dean of midwifery school since 2014. Suryati Romauli graduated as Bachelor of Midwifery then continued her study in Master of Public Health in Hasanuddin University Makassar. Flora Niu graduated as Bachelor of Midwifery after that took her Master of Midwifery in Hasanuddin University, Makassar City.

\section{Volume 6 Issue 7, July 2017 www.ijsr.net}

